\title{
INDONESIAN SUFI IN MALAY WORLD A Preliminary Exploration with Reference to Tariqa Naqshbandiyya-Khalidiyya Babussalam (TNKB)
}

\author{
Ziaulhaq Hidayat
}

UIN Sumatera Utara, Medan - Indonesia | ziaulhaq.phd@gmail.com

Muzakkir Syahrul

UIN Sumatera Utara, Medan - Indonesia | muzakkirsyahrul@yahoo.com

\begin{abstract}
This article is an initial exploration of Indonesian Sufi, developed in the Malay world of Indonesia and Malaysia. The spread of this particular tariqa (sufi's order) relates specifically to the mandate received by Tuan Guru of TNKB, as its certified Shaykh, who then actively involved in the network acitivity by visiting the Malay Sultanate areas scattered in the Malay Peninsula. This research reveals the incorporation of some elements of different tariqas in the "form" of TNKB, such as Tariqa Shazaliyya and Tariqa Sammaniyya, as well as adaptation of local culture of Malays ethnic which become part of its unique ritual. Supported by the Sultan, TNKB has become the "official order" of Malay Sultanate, which covers area of Riau, Sumatera Utara (North Sumatera) in Indonesia as well as Johor in Malaysia-with caliph as its "agent".
\end{abstract}

Keywords: Indonesian Sufi; TNKB; Tuan Guru, Caliph and Malay World

\section{Introduction}

As one of the biggest tariqas in the Malay World, the notable influence of Tariqa Naqshbandiyya-Khalidiyya Babussalam (TNKB) is closely related to the "mandate" received by Tuan Guru-due to his sufi's lineage-which eventually formed a sufi network. In TNKB's tradition, every caliph (after confirmed as a murshid) has the obligation to embrace the network in their hometown. For this reason, Tuan 
Guru1, as the founding father of TNKB, is directly involved in the development of TNKB at Malay world; not to mention the fact that he himself is part of Malay ethnics, which of course has the advantage in gaining trust and better understanding.

The sufi networks of TNKB offers a unique sufi models, for this tariqa consists of various elements of different tariqas in it. This combination is a model commonly found in Indonesia, and may represent Indonesian sufi model. ${ }^{2}$ Moreover, another element that confirms TNKB Sufi Indonesia as a model is found in some ritual practices adopting local cultural traditions, especially the developing tradition of Malay society. Local cultural elements in this TNKB is certainly not found in other tariqas. This common entity is only found in Indonesia called as trans-national-because it comes from the Middle East-experienced localities with traditions that lives and thrives in the community.

The spreading of TNKB in Malay world for their "intimate relationship" with the local authorities, especially the Malay Sultans, is almost throughout the Malay Peninsula in Indonesia and Malaysia because it is supported by the authority. Power relation which has developed between TNKB and Sultan is of course a reciprocal relationship, especially TNKB with the Sultan who needs each other. Malay Sultan also needs the legitimacy of the spiritual to the interested power because Malay community is very strong in keeping their Islamic identity which is something very important in people's life. Instead of it, TNKB also can spread widely in the Malay world because there is a support from Malay Sultans positioning them as a part of the power.

\footnotetext{
1 Tuan Guru in this article generally refers to murshid or leader of tariqa-In this context-is devoted to Shaykh 'Abd al-Wahab Rokan (d. 1926) as the first murshid of TNKB. The use of Tuan Guru term is commonly applied in Malay world refering to the spiritual leader, although there is still a shift in the use of it which refers to the religious leaders in general.

2 The combination model in some tariqas in Indonesia is common such as the combination of Tarekat Qadiriyah wa Naqsyabandiyah (TQN), Tarekat Khalwatiyah wa Samman (TKW). Merging this tariqa, by among scholars such as Martin van Brunessain (1994), Itzack Wesmann (2007), and others, is regarded as a form of response tariqa against colonization that takes place in Indonesia, but in the case of TNKB which becomes my focus explains that the authority and the collection of several diploma of murshid are a major part in the effort of merging some tariqas.
} 
TNKB network in the Malay world is formed because there is a strong network of "agent" who becomes a connection among regions in Malay world, because it is based on existing records that the life of Tuan Guru TNKB tends to move from one empire to another which has a positive implication in the effort of new network development. Every time, Tuan Guru transits from one country to another. He always inaugurates caliphates that would be the "agent" and practice TNKB which has a moral responsibility to be actively involved in efforts to strengthen TNKB network. The network formation done by Tuan Guru is certainly shaping efforts to strengthen it, especially in Malay world which becomes "principal claim" in spreading the tariqa. TNKB network in Malay world is very apparent in the next generation which is also likely to "pass" to dhurriyat as progressor of TNKB to form a wider TNKB network than before. But for the sake of this article, it will be limited to a network trace of TNKB at the first generation, precisely on TNKB main teacher, Shaykh 'Abd al-Wahab Rokan (d. 1926)

So far, there hasn't been a deepest research of TNKB in Malay world, especially the initial TNKB network, but some scholars recognize TNKB network in Malay world is very strong as it is mentioned by Denis Lombard, ${ }^{3}$ Martin van Bruinessen, ${ }^{4}$ Wernes Kraus, ${ }^{5}$ Daniel Perret, ${ }^{6}$ Itzack Wesmann, ${ }^{7}$ and others that the existence

${ }^{3}$ Denys Lombard, "Tarekat et Entreprise à Sumatra: L'exemple de Syekh Abdul Wahab Rokan (c.1830-1926)," Marc Gaborieau, et.al. (ed.), Naqshbandis: Cheminements et Situation Actuelle d'un Ordre Mystique Musulman (Paris: Institut Français d'études Anatoliennes d'Istanbul, 1990), p. 710; Denys Lombard, "Les Tarekat en Insulinde," Alexandre Popovic and Gilles Veinstein (eds), Les Orders Mystiques dans l'Islam: Cheminements et Situation Actuelle (Paris: l'École des Hautes Etudes en Sciences Sociales, 1986), p. 146.

${ }^{4}$ Martin van Bruinessen, Tarekat Naqsyabandiyah di Indonesia: Survei Historis, Geografis dan Sosiologis (Bandung: Mizan, 1994), p. 108; Martin van Bruinessen, "After the Days of Abu Qubays: Indonesian Transformations of the Naqshbandiyya Khalidiyah," Journal of the History of Sufisme, 21: 5 (2007): pp. 225-251.

5 Werner Kraus, "Some Notes on the Introduction of the Naqshbandiyya-Khalidiyya into Indonesia," M. Gaborieau, A. Popovic and Th. Zarcone (eds), Naqshbandis: Historical Developments and Present Situation of a Muslim Mystical Order (Istanbul and Paris: ISIS, 1990), p. 651.

${ }^{6}$ Daniel Perret, La Formation d'un Paysage Ethnique Batak et Malais de Sumatra Nord-Est (Paris: Ecole francaise d'Extrême-Orient, 1995), p. 145 ; Daniel Perret, " De la Forêt Primaire Aux Plantations Coloniales: Les Deux Ruptures Politiques et Socio- 
of TNKB as a tariqa has a great influence in Indonesia and Malay peninsula. This research is done to complete the existing assessments, particularly reviewing TNKB Sufi in Indonesia as a model that has an extensive network in the region of Malay world. This article will also explain the identity of TNKB Sufi in Indonesia as a model and pattern formation and TNKB network development in Indonesia and Malay world.

\section{TNKB as Sufi Model in Indonesia}

TNKB as a typical model of Indonesian sufi can be seen from the various elements in the "body" of TNKB. Sufi identity is in the "body" of TNKB, although it is known affiliated to the Naqshbandiyya-Khalidiyya, but in practice this tariqa has many other tariqas elements in it. Another form of tariqa in TNKB, of course, is the unification effort from several tariqas in the entity of TNKB, which is the creativity of TNKB founder-then also-negotiated with local cultural elements in shaping TNKB form, especially in the practice of ritual — as has been formalized-in the tradition of TNKB. Entities tariqa called, both creative merger of several institutes and the idea of entering the local culture becomes a part of TNKB uniqueness - as well as-becomes a special identity of Indonesian sufi, because the entity called-as far as I know-in the form of sufi in other regions, ${ }^{8}$ hence TNKB sufi can be called as a sufi model tariqa transnational Indonesia made into the locality and the unification of some elements of the tariqa, and seeks to combine them with elements of the culture in the form of TNKB local identity.

This kind of tariqa merging model is a common model found in Indonesia, then certainly TNKB as a part of typical model in Indonesian sufi merges with several elements in a single institute that is Indonesian sufi. Besides, the incorporation of several tariqas confirms

économiques de la Côte est de Sumatra-Nord," Bulletin de l'École française d'ExtrêmeOrient, 81 (1994), p. 177.

7 Itzchak Weismann, The Naqshbandiyya: Orthodoxy and Activism in a Worldwide Sufi Tradition (New York: Routledge, 2007), p. 40.

8 As far as my observation done, the adaptation of local elements in the tariqa transnational generally occurs in particular ethnic. For example, Tariqa Shattariyya is derived from Ulakan, West Sumatra also shows Minangkabau cultural identity in this tariqa. Likewise Tariqa Khalwatiyya which grows in Sulawesi is also seen Bugis ethnic cultural identity in the face of Tariqa Khalwatiyya. 
that Tuan Guru as murshid does not only have a diploma institute, but also has another genealogical networks, ${ }^{9}$ then this tariqa merging model is a model form of Indonesian sufi, which has tendency still accommodating with local cultural elements in it. TNKB as transnational tariqa experiences to locality elements appears in the form of the tariqa, so that it blends in tradition that develops in society, especially Malays as a base-camp for distributing TNKB ${ }^{10}$. For TNKB experience, merging some elements of this order can be seen from the written testament of TNKB founder, which opens space on the other tariqas, apart from the Naqshbandiyya-Khalidiyya as this order known. ${ }^{11}$

This written testament explains that the founders of TNKB is a part of successor at other tariqas for cues mentioned that there is equivalency between TNKB with other tariqas. According to local sources, the actual founder of this TNKB before obtaining a Naqshbandiyya-Khalidiyya diploma in Mecca, he has received the ijaza of Shazaliyya Tariqa when he was in Riau. ${ }^{12}$ Apparently, it is the background of TNKB founder which attempts to merge the Naqshbandiyya-Khalidiyya with Shazaliyya Tariqa in the "body" of TNKB, even though TNKB is better known as the NaqshbandiyyaKhalidiyya, but the actual elements of Shazaliyya Tariqa can be seen clearly in ritual taught by TNKB. ${ }^{13}$ At the practice of ritualstandardized - in this tariqa is also found other elements of two tariqas namely Sammaniyya Tariqa existing in TNKB ritual. As far as the assessment is done, merging tariqas in $\mathrm{TNKB}$ can be explained as follows:

9 'Abd al-Wahab Rokan, Wasiat 44 (n.p.: n.p., n.d.), p. 1; Arif Zamhari, "SocialStructural Innovations in Indonesia's Urban Sufism: The Case Study of the Majelis Dzikir and Shalawat Nurul Mustafa," Journal of Indonesian Islam, 7:1 (2013), p. 125.

10 Ziaulhaq, "Tarekat Naqsyabandiyah-Khalidiyah Babussalam (TNKB): Situs, Silsilah dan Jaringan," Jurnal Turats, 2: 1 (2014).

11 Tuan Guru testament is a written script which allegedly direct writing of Shaykh "Abd al-Wahab Rokan which is popularly called "wasiat 44". One of the contents of this testament states that "... when already you are of legal age, understanding, let receive Shazaliyya or Naqshbandiyya sufi order, that you're in line with me".

12 Interview with Athardin, 56 years old.

${ }^{13}$ Bruinessen, Tarekat Naqsyabandiyah, p. 108. 


\section{Adherence to Sharia}

Normatively, Naqshbandiyya and Shazaliyya Tariqa have an element of proximity, especially in terms of orthodoxy shari ${ }^{6}{ }^{14}$ which is a well-established doctrine in the tradition of both tariqa. In the context of TNKB, it is very clearly and visible that shari'a compliance is something very important because shari'a as a requirement for salik to be accepted as a part of TNKB successors. ${ }^{15}$ This shari'a requirement is very tight, especially for the initial establishment of this institute. However, in a recent development elements of the obligation on shari'a knowledge, especially referring to figh, it is rather loosely applied as it relates to the existence of Tuan Guru which is no longer able to represent leadership of murshid, then of course the consequence of such shifts tends to weaken the insight of shari'a for TNKB successor. ${ }^{16}$

The hierarchy of knowledge in TNKB can be seen from knowledge structures which are built starting from shari'a and-nextthe nature of course confirms that elements of shari'a is an important thing for TNKB, because it is believed that the first step must be passed by salik to explore the science of shari ${ }^{6},{ }^{17}$ then of course the same tendency is also found in Shazaliyya Tariqa that puts shari'a as the basic experience of the tariqa. The closeness of the two tariqas would be as a merger of this tariqa in TNKB experience, then the model merging of the tariqa, called a model of growing tariqas in Indonesia, is also found in other tariqas by considering relevance elements to the needs of the tariqa, as well as the social and political situation facing in its development.

\footnotetext{
14 Syofyan Hadi, "Naskah Mawahib Rabb al-Falaq: Melacak Titik Temu Ajaran Dua Tarekat (Syazaliyah dan Naqsyabandiyah) di Minangkabau," Lektur Keagamaan, 11: 1 (2013), p. 115; Sulanam, "From "Sufi Order Ritual" to Indonesian Islam," Journal of Indonesian Islam, 7:1 (2013), p. 215.

15 Ziaulhaq, "Sharp Skullcap (Lobe Runcing) of Tariqa Naqshabandiyya-Khalidiyya Babussalam (TNKB): Identity, Sacredness and Commodity," Proceeding in International Conference on Southeast Asian Islam: Legacy and New Interpretation, UIN Jakarta, 2014b.

16 Ziaulhaq, "Tarekat Naqsyabandiyah-Khalidiyah”, p. 122.

17 Fuad Said, Syeikh Abdul Wabab Rokan: Tuan Guru Babussalam (Medan: Pustaka Babussalam, 1983), p. 12; M. Iqbal Irham, "Pemikiran Sufistik Syekh Abdul Wahab Rokan,” Jurnal Lektor Keagamaan, 8:2 (2010): pp. 279-314.
} 


\section{Suluk Ritual}

Merging tariqa element in TNKB can also be seen in the mysticism ritual taught at $\mathrm{TNKB}$ which is also rather difficult to distinguish between the practice of mysticism known in Shazaliyya and Naqshbandiyya ritual, because both are almost similar, both in the technical implementation or time done by suluk between 10, 20 and 40 days. Implementation of mysticism is deeply experienced by TNKBexecuted every time, because it is the pilgrims who come to perform the ritual mysticism which is never empty - from the beginning of its establishment until now-because it relates specifically to the TNKB network in Malay world, then certainly pilgrims visiting, either for pilgrimage or mysticism continued until the present. My most recent observation shows that TNKB continues to make improvements by providing good facilities, such as a representative and convenient dormitories for salik which is also attended by strengthening of TNKB identity.

Another element which is found in TNKB is the effect of Sammaniyya Tariqa in rituals performed, especially in the implementation of the rituals of remembrance as practiced by TNKB that is "samman dhikr" to explain that the ritual of remembrance performed is adopted from Samman Tariqa. "Saman dhikr" rituals is different from the traditional ritual known by Naqshbandiyya, because public ritual performed by vague (sirr) is different from the Samman popularize the ritual using hard voice (zahar). ${ }^{18}$ In TNKB experience, dhiker rituals performed by following the pattern of remembrance Samman Tariqa by doing dhikr with loud voice, then certainly TNKB adopts the model of ritual of Samman becomes part of the ritual tariqa. To that end, the model of "samman dhikr" reinforces the model merging tariqas in the form of TNKB as a model developed in Indonesia.

\section{Local Cultural Adaption}

Another characteristic of TNKB is an attempt to accommodate local culture, especially Malay ethnic culture because as it is explained before that this TNKB is widespread from Malay ethnic region. Malay cultural adaptation shows that TNKB, as the tariqa, is able to negotiate

\footnotetext{
${ }^{18}$ My observations to TNKB expression is remembrance of Saman implementations carried out in a loud voice that lacks with his head to the right and to the left while remembrance.
} 
with the local culture, so TNKB is not only a part of spiritual order, but more than that it becomes spiritual identity of Malay TNKB spreading in Indonesia and Malaysia. Adaptation to local culture in TNKB experience is specifically related to the existence of this order in the Malay society, so that the local cultural adaptations that do something unavoidable assert that TNKB is able to accept the local culture as part of the local cultural identity of this tariqa.

This local culture can be seen in the practice of TNKB ritual such as early procession in receiving tariqa started with a lime submitted to Tuan Guru to pray. ${ }^{19}$ Kaffir lime is cut to be like a part of the implementation of the bathing ritual of repentance. This ritual is unknown at another tariqa because it sources from local cultural traditions of Malay ethnic. The practice of bathing by using lime is known within the Malay community, ${ }^{20}$ especially to cleanse the physical and spiritual. Therefore, the practice of ritual goes into TNKB, so this element of local culture is evident in the entity rituals prevailing at TNKB.

\section{Malay Sultan Supports Tuan Guru}

TNKB network in Malay world is specifically related to the support of Malay sultan, because this tariqa is generally accepted as "official spiritual order" in the region of the Malay Peninsula, both of which entered the territory of Indonesia or Malaysia. ${ }^{21}$ TNKB is not only accepted as a religious reference, but more than that Malay sultans give a large space on the network dissemination TNKB, so TNKB is widespread in the Malay world. The supporting of Malay sultan to $\mathrm{TNKB}$ can be seen in the perspective of a spiritual relationship with power, which indeed they need each other to one another in the bonds of intimate relationship. Malay Sultan as the local authorities cannot be

\footnotetext{
${ }^{19}$ Muzakir, "Dari Sakral ke Profan: Globalisasi dan Komodifikasi dalam Dunia Spritual dengan Ilustrasi Tarekat Naqsyabandiyah-Khalidiyah Babussalam (TNKB)," Akademika, 20:1 (2015), pp. 5-8; Khairil Fikri, "Etnografi Suluk Tarekat Naqsyabandiyah-Khalidiyah Babussalam (TNKB)," Ziaulhaq Hidayat, Tarekat Naqsyabandiyah-Khalidiyah Babussalam (TNKB): Dari Doktrin, Seni bingga Arsitektur (Jakarta: LSIP, 2015), pp. 97-122.

20 Ritual bath with lime is the tradition of the Malay community which is also performed in important moments such as welcoming the month of Ramadan and the person who will perform Hajj.

${ }^{21}$ Bruinessen, “After the Days of Abu Qubays, p. 226.
} 
separated from the Islamic identity which needs to strengthen the powers of spiritual legitimacy. Instead, Tuan Guru also needs support to strengthen the power distribution network in the world with Malay power.

This spiritual affection is considered important in the context of local and global nets of TNKB in the Malay world, because it will be explained that Tuan Guru in the projected distribution network always moves in Malay Peninsula. Moving from one place to another done by Tuan Guru is certainly a part of strengthening TNKB identity in Malay world. It explicitly referred to the existence of TNKB, especially Tuan Guru-when it is known as a spiritual figure who has a great influence in Malay society, thus "forcing" the Sultan of Malay for "race" makes TNKB as part of its remit. ${ }^{22}$ The attitude of Sultan is specifically that the Malay society abiding positioned spiritual elements into something that is important in their life, then certainly a spiritual element to the Malay sultan is something very important in the effort to legitimize "perpetuation" of power. To that end, Tuan Guru certainly gets many offers to stay and settle in the Malay sultanate. In relation mentioned above, TNKB gets full support from Malay sultans to strengthen its existence in Malay world, then of course this projection network will be strengthened in the Malay world as Tuan Guru himself always moves as part of efforts to strengthen the dissemination and TNKB network.

According to local records, after Tuan Guru returns from "nyantri" in Mecca, firstly he visits his birthplace in Rantau Binuang Sakti, Riau. When in Riau, Tuan Guru starts its activities as a spiritual figure, so this initial phase Tuan Guru has successfully recruited several worshipers-then-be caliph. ${ }^{23}$ In addition, when still in Riau, Rokan also manages to build a settlement named "Kampung Masjid" as the center of activity in the area of TNKB Siak, Riau. Then, when in Riau Tuan Guru is able to attract the attention of many people, including Sultan Zainal 'Abidin as the ruler of the Sultanate Tambusai-thenasked him to stay in the Sultanate that he led. Based on the Sultan's

${ }^{22}$ Common reference used to describe the journey of life of Tuan Guru TNKB refers to local sources written by Fuad Said, entitled "Syeikh Abdul Wahab Rokan: Tuan Guru Babussalam”.

${ }^{23}$ Yusri Syam, et.al., "Pengkajian Perguruan Naqsyabandiyah Rantau Binuang Sakti," Report, Pemerintah Kabupaten Rokan Hulu, Kantor Pariwisata dan Kebudayaan, 2006, p. 85. 
request, then temporarily Tuan Guru settled there and play the role of a spiritual figure who is respected and admired by many people in the community with major activities is teaching. In addition, Tuan Guru has also participated actively in the establishment of regionally based on organizations led by Sultan Zainal 'Abidin which makes Tuan Guru known widely by the people not only in Riau, but also in the other Malay sultanate. ${ }^{24}$

Not long stay in Riau, Tuan Guru receives an invitation to visit the country to the other Malay Sultan, then the invitation of Sultan Ishaq as ruler of the Sultanate of Kualuh when he lived there as a spiritual figure. The existence of the Sultanate of Kualuh is also part of the distribution network in the Malay world, because it is noted that when he is in Sultanate of Kualuh he is able to induct some caliph's liaisons of TNKB network in the region. ${ }^{25}$ It is important to be mentioned that each caliph appointed by Tuan Guru has become as well as the TNKB agent network, then every sultanate has always left the caliphate in the region. Then, the caliph who is inducted also have an obligation to actively disseminate TNKB in the area where he lives and settles. ${ }^{26}$ To that end, it is understood that the deployment of Tuan Guru done by extending the "agent" in various regions would widen TNKB network. Another Malay Sultanate who has an important role in disseminating of TNKB is Sultanate of Langkat, because the empire-called when it-leaded by Sultan Musa Shah who is not only provided a broad space to Tuan Guru, but he himself is precisely to be part of TNKB as caliph involved active in supporting the dissemination of TNKB. ${ }^{27}$

By his position as a caliph, Sultan Musa opens the availability of full support in the development of TNKB by providing representative headquarters and economic support for efforts to strengthen the network in the world of TNKB Malay. ${ }^{28}$ Tuan Guru cordial relations with local authority of Langkat Sultanate is not only during his tenure,

\footnotetext{
${ }^{24}$ Said, Syeikh Abdul Wahab Rokan, p. 42.

25 Ibid., p. 43.

26 Lisga Hidayat Siregar, "Tarekat Naqsyabandiyah Syekh 'Abdul Wahab Rokan Babusalam: Suatu Kajian tentang Ajaran dan Aktualisasinya dalam Kehidupan Sosial 1882-1926, Unpublished Ph.D Dissertation, UIN Syarif Hidayatullah Jakarta, 2003; Muzakir, "Dari Sakral ke Profan", p. 9.

27 Lombard, "Tarekat et Entreprise à Sumatra, p. 711 ; Bruinessen, Tarekat Naqsyabandiyah, p. 135.

${ }^{28}$ Perret, La Formation d'un Paysage, p. 163.
} 
but also continues on the next sultan until the current leadership which is now very clearly visible "intimate relationship" both. ${ }^{29}$ Sultanate of Langkat gives a great support to this TNKB to give the autonomous region for which TNKB - till today—is the only Naqshbandiyya which has its own settlement. ${ }^{30}$ Support local authorities have a big influence on efforts to strengthen the network in the Malay world of TNKB provided their support for such power. Important known, until today in TNKB area otonom. This is a region can be used for the benefit of TNKB for their covenant between Tuan Guru with Sultan Langkat. ${ }^{31}$

Autonomous region granted to TNKB by Sultan Langkat can be established to build a network base to the region of the Malay world, because when inception TNKB is able to build a representative township to be the basis of TNKB activity, which is followed by the economic development efforts with an entrepreneurial spirit. Noted that TNKB has developed various business sectors such as farming pepper, fish farming, goat farming, and others. ${ }^{32}$ Economic establishment built by TNKB is of course entirely a support Sultan Langkat, ${ }^{33}$ because without the support of Sultan Langkat certainly the attempt to run economy creativity by TNKB cannot be developed properly, so TNKB - at that time-has the economic establishment making it easier for expansion its network at Malay world. Early development of this TNKB has managed to collect pilgrims which are living independently and providing services to vulnerable groups such as the poor, widows, orphans and others by providing shelter and education as it should be. ${ }^{34}$

${ }^{29}$ The latest source that I got to explain the "intimacy" of Tuan Guru TNKB with Sultan Langkat, ie some handwritten letter Tuan Guru addressed to Sultan Langkat which contains about who will be replacing him as a leader of TNKB after he died and some advices to the Sultan Langkat, These letters are now collected by the family of the Sultanate Langkat and its copy is with me.

30 Weismann, The Naqshbandiyya, p. 41.

31 This agreement contains a letter of appointment nazir waqf Sultan Langkat to Tuan Guru TNKB and its lead will be followed by his zuriat. The existing agreement letter are in zuriat collection of TNKB and Sultan Langkat Family.

32 Lombard, "Tarekat et Entreprise à Sumatra, p. 711.

33 Perret, La Formation d'un Paysage, p. 162.

34 Ziaulhaq, "Tarekat Naqsyabandiyah-Khalidiyah", p. 122; M. Amin Syukur and Abdul Muhaya, "al-Harakah al-Iqtisadiyah al-Sufiyyah fi Jawa: Dirasah Waqiiyah li Tariqah al-Qadiriyah wa Naqshabandiyah,” Journal of Indonesian Islam, 9:2 (2015), p. 224. 
This project of dissemination of TNKB network in the Malay world is continued by Tuan Guru to visit Malaysia, exactly at Johor Sultanate leaded by Sultan Abū Bakar bin Ibrahim. Not much different from the other Malay sultans, he also considers that the visiting of Tuan Guru to the region is an important part in the efforts to strengthen the power of the sultan. He also asks Tuan Guru as a part of his empire by positioning him as a spiritual teacher. The existence of Tuan Guru in Malaysia can be called as a part of the mission in spreading TNKB network at Malay Peninsula, because Tuan Guru while in Johor Sultanate also manages to inaugurate several caliphs in Batu Pahat as it will be explained in further discussion, which finally they become an agent of TNKB in this region, which until now it traces TNKB is very strong and growing in this area. In the process, especially when Tuan Guru is still in Malaysia, he makes a visit to Malacca also to manage a network in the region. So TNKB network in Malaysia becomes stronger as other Malays in Indonesia because the caliphs inducted by Tuan Guru is active and at the same time to liaise when-will-Tuan Guru comes back to Langkat, Sumatra Utara, Indonesia.

In Indonesian context - certainly — that Tuan Guru has visited almost all the existing Malay Sultanate, such as Asahan Sultanate, Batubara Sultanate, Bilah Sultanate and so on. Agenda visited by Tuan Guru to the region of the Sultanates would have serious implications in the efforts to establish a TNKB network in the area he visited, then the influence of TNKB in the Malay world is very clearly visible, especially at the moment of haul that all the successors mentioned above actively come to TNKB in Langkat, Sumatra Utara, Indonesia. ${ }^{35}$ In addition, the success of TNKB network built by Tuan Guru is of course completely inseparable from the support of Malay Sultan as the local rulers at the time. Therefore, the network TNKB in Malay, Indonesia and Malaysia, is a part of the dialectic power that takes place between Tuan Guru and Malay Sultans as the local authorities in the area of Malay Peninsula.

35 When there is a haul in 2015, I myself who writes the number of buses coming which consists of a hundred buses in 3 days. And added with the private cars and motorcycles, so the visitors are thousand visitors, which come from Malay world in Indonesia and Malaysia. 


\section{TNKB Network in Indonesia and Malaysia}

Generally, TNKB network can be called quite influential in the region of Malay world, because its spread is intensively carried out in this region. TNKB deployment in the Malay world can be seen from the spread of TNKB caliph in some regions in Malay. ${ }^{36}$ Projection is widely implemented during the next generation of Tuan Guru for network dissemination efforts till now, which is certainly greater than ever. "Agency system" done by TNKB will continue to expand the number of networks in every region contained its agency.

Picture 1. Network of TNKB

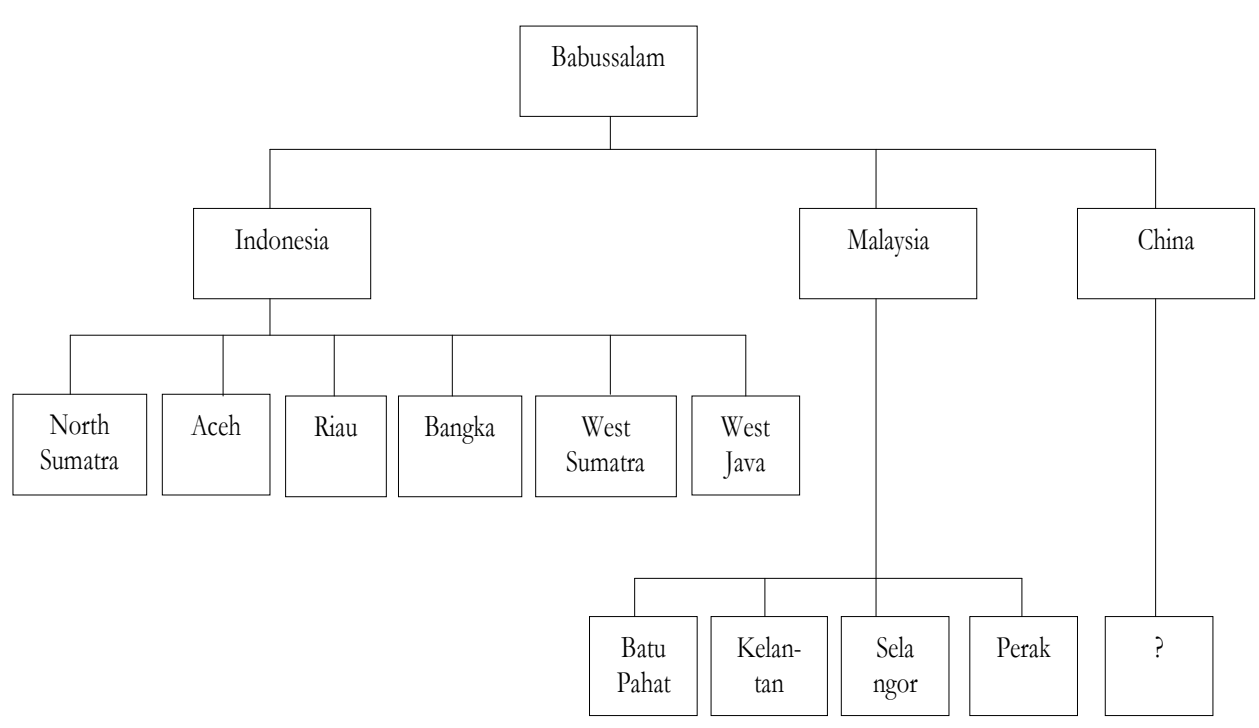

Source: Script of Caliph List Drawn by Tuan Guru of TNKB

Referring to the script of caliph list above, it can be seen the number of its spread in Indonesia and Malaysia, which plays a role in the dissemination efforts of TNKB network in Malay world. In addition, it is important to be known that TNKB network in the Malay world also includes Singapore territories, Thailand and Brunei Darussalam. ${ }^{37}$ In these areas do not reveal any persulukan activity

\footnotetext{
36 Ziaulhaq, "Tarekat Naqsyabandiyah-Khalidiyah”, p. 122.

${ }^{37}$ Caliph networks in a country beside Indonesia and Malaysia, are generally only perform activities tariqa alone which does not form suluk home network, or also zuriat
} 
permanently like mysticism home, but it is certain that TNKB network formed after the next generation is to strengthen TNKB in the Malay world. ${ }^{38}$ It is also found the existence of a caliph network who comes from China, but it is quite unfortunate that its communication network is disconnected, so it is not known whether this network still exists or not.

\section{Indonesian Network}

Rian

TNKB network in Malay world, especially in Riau, is an influential network, because it has been mentioned that after Tuan Guru returns from Mecca, he immediately visits his family in Riau and doing his mission to develop TNKB in this area. TNKB network in Riau is important because Tuan Guru himself comes from this area, so that efforts to spread it also can be called difficult because before leaving Mecca, he has been known as a religious man. Because in Riau, TNKB murshid is known as an expert in law, especially in the field of jurisprudence, so he is regarded as "jurist". ${ }^{39}$ However, TNKB network in Riau is not only NaqshbandiyyaKhalidiyya network that effects people because it is found also another network having influence in this area, namely Naqshbandiyya-Khalidiyya network who comes from West Sumatra because Riau region is directly near to the this area, then of course the deployment of other networks cannot be avoided. According to local sources, TNKB network in Riau, precisely in Rokan Hulu, recorded since 1900, has been found to have an institution affiliated to TNKB, then of course long before TNKB in Riau has spread widely to Malay community, ${ }^{40}$ especially at the area believed to be the most widespread network of tariqas, both of TNKB network or other networks. For Rokan Hulu for example, recently this area has a nickname called "the land of a thousand suluk" because it explains that in

networks who live in those countries generally will be actively involved in TNKB at the moment of haul, because for zuriat haul moment is also a form of reunion on zuriat scattered throughout the world to meet and gather in Babussalam Langkat. Interview with Shalahudin, 41 years old.

38 According to information from Tuan Guru now-generation 9th at 2015, he has inaugurated more than a thousand caliph. Interview with Syarwani Hashim, 71 years old.

${ }^{39}$ Said, Syeikh Abdul Wabab Rokan, p. 43.

40 Tajuddin, Sejarah Almarbum Waliyullah Qutuburzaman Syeikh Abdul Wabab Rokan Tuan Guru Babussalam (n.p.: n.p., n.d.), p. 1. 
this area we can find many tariqa networks, one of them is TNKB network - so far-at least, there are 41 (forty-one) suluk bouse, ${ }^{41}$ that clearly connects on pedigree of TNKB. TNKB network in this area is known as the strengthening of TNKB network in the Malay world because, as it is generally that this TNKB tends to be inherited from one generation to the next, and it continuities genealogy tariqa referring to TNKB from one generation to the next generation.

So far this assessment made, there is no official data that records the amount of TNKB network in Riau, but based on distribution of TNKB caliph, it can be understood that almost the entire areas of Riau TNKB have connective network, then of course TNKB in Riau has a significant impact in strengthening TNKB network in Malay world. In addition, TNKB network growing in Riau is also found that there is sourced from TNKB network coming from Malaysia, because there are some suluk house from caliphs of Tuan Guru TNKB-who originally-stay in Malaysia and move to Riau, even though TNKB network from Malaysia is not many, but it is able to explain that the strengthening of TNKB network in Riau or Malaysia itself as an affirmation of TNKB network in Malay world as a whole because this tariqa is specifically made its way to the region.

The trail network in Riau is also strengthened by the project of Islamization in Sakai ethnic suspected as the Malay ethnicities. Some studies explain that the role of TNKB in an attempt of Islamization is quite successful because TNKB performs cultural approach in carrying out that mission, so many Sakai ethnic are eventually interested to be a part of TNKB successor. ${ }^{42}$ The successful of TNKB because it is able to adapt different ethnic and peaceful coexistence, so that efforts can be done in a peaceful Islamization and able to ensure that TNKB is as one important parts for the ethnic life. The influence trace on Sakai ethnic is clearly seen that some caliphs of TNKB spread in Riau, especially in the area of Sakai ethnic in Duri, so caliphs who came from Riau make TNKB stronger. TNKB network in Riau can also be seen from the influence of TNKB politics because some caliphs are also actively involved in government, either as leaders or staffs who are also aggressively to strengthen TNKB network. Strengthening networks in

\footnotetext{
${ }^{41}$ Syam, et.al., "Pengkajian Perguruan Naqsyabandiyah", p. 87.

${ }^{42}$ U.U. Hamidy, Pengislaman Masyarakat Sakai oleh Tarekat Naksyabandiyah Babussalam (Riau: UIR Press, 1992), p. 47; Parsudi Suparlan, Orang-orang Sakai di Riau: Masyarakat Terasing dalam Masyarakat Indonesia (Jakarta: Yayasan Obor Indonesia, 1995), p. 195.
} 
this context relates specifically to the existence of positions held as legitimacy and sustain the positions held.

These influences are involved in the policy or activities carried to strengthen TNKB network with community involvement. Similarly in Riau, to strengthening the network is also through special educational institutions established as boarding schools affiliated to TNKB. Through this educational institutions, TNKB identity can be seen clearly and the dissemination efforts of TNKB doctrine through educational institutions to young generations have an influence in strengthening the network project of TNKB in Malay world. ${ }^{43}$ Therefore, it can be called TNKB network in Riau capable of playing an important role in community life, especially in politics and government, because there are several caliphs or TNKB dhurriyat involves in a politically_suspect-successful political career because it is supported by TNKB given the strength of TNKB network in this area. The influence of TNKB in Malay world seems different from other regions in a community political life because in this area affiliated group in TNKB is particularly involved in politics, then certainly many of the policies undertaken in an effort to strengthen its existence and expand the network TNKB in the area, so that the effect of TNKB in Riau looks strong in people life who become spiritual and cultural reference for Malay society which has become a part of the cultural identity for its society.

\section{Sumatra Utara Network.}

TNKB network in Sumatra Utara is entirely related to the role of Tuan Guru who plays an active role in the deployment of this order in Malay world. TNKB network-as mentioned above-specifically done by Tuan Guru by visiting Malay Sultanate in Sumatra Utara, all of which are understood as part of efforts to disseminate TNKB network. TNKB network can be seen from the number of caliphs as an agent of TNKB spreading to all corners of Malay world. According to local sources, Tuan Guru has inaugurated at least 156 (one hundred and fifty six) caliphs scattered in various areas, especially the Malay community. All of caliphs are actively in efforts to strengthen TNKB network in the area of origin by forming a community affiliated to TNKB such as building a suluk house or assemblies of remembrance,

43 According to information from Tuan Guru now-generation $9^{\text {th }}$ at 2015, he has inaugurated more than a thousand caliphs. Syarwani Hashim, 71 years old. 
although there is still a part of the caliph is passive, but anyhow they still connect to the TNKB. So far, the network TNKB in Sumatra Utara-based on Malay ethnic who is directly involved in efforts to strengthen TNKB network who is a direct caliph of Tuan Guru listed among caliphs is Khalifah Junaid in Labuhan Bilik, Khalifah A. Thaib in Gunung Selamat, Labuhanbatu, and others. ${ }^{44}$

From all caliphs mentioned above. All of them have passed TNKB network to their dhurriyat until today, from one generation to others till their grandchildren, who also continue to connect TNKB. TNKB network through caliphs are actively involved in the dissemination of TNKB network, especially in the area of origin. Not only that, the caliphate plays a very important role in the deployment of this network because generally the caliphs has social important level in the community as the community leaders and also spiritual teachers to make it easier for the caliphate in running job as "an extension hand" of TNKB.

TNKB network in Sumatra Utara can be seen for example in Kualuhnow it is called Labuhanbatu Utara-Tuan Guru doest not only develop education institute, but also builds a village called "Kampung Masjid" 45 which until today still exists as a network trace of TNKB with many suluk bouses spread at various districts massively because Tuan Guru has ever a connection with Kualuh Sultanate. It is suspected that the dissemination of TNKB in this area rose for their acceptance of the community and supported by legitimation of Kualuh Sultan. It is not much different from TNKB network in Panai, Labuhanbatu, which is also clearly visible trace and TNKB network in this area with a lot of suluk bouses affiliated to TNKB, then it is also reinforced by Khalifah Junaid—as it has been mentioned before—as murshid regional liaison TNKB network in this area. Khalifah Junaid is appointed as a caliph by Tuan Guru, which is given a mandate to teach and disseminate TNKB in the surrounding area. Khalifah Junaid's role in strengthening TNKB network, particularly in Labuhanbatu, can be seen by many pilgrims who follow suluk at his suluk house that nowadays it is continued by his dhurriyat at Sungai Penggantungan, Labuhanbatu.

Caliph network that also has an important role in Labuhanbatu is Khalifah A. Thaib from Gunung Selamat, Labuhanbatu Selatan. Khalifah A. Thaib has an extensive network for South Labuhanbatu area to other areas that have network connections because of its

\footnotetext{
${ }^{44}$ Siregar, "Tarekat Naqsyabandiyah", p. 59.

${ }^{45}$ Said, Syeikh Abdul Wabab Rokan, p. 48.
} 
position not only as a spiritual teacher in TNKB, but more than that he also has a role as religious leaders among the people of South Labuhanbatu at that time. In an effort to disseminate this TNKB, he has pesantren (Islamic boarding school) as a base of Islamic education, which would participate in the strengthening of TNKB network.

\section{Malaysia Network}

As it has been mentioned above that Tuan Guru in the distribution projected of TNKB network is also been settled in Malaysia around 1888 , then of course it is certain that the TNKB network also scattered in the area of Malay in Malaysia because Tuan Guru is also been settled several days in Johor and Malacca. According to Bruinessen, ${ }^{46}$ TNKB network scattered in different parts of Malaysia such as in Kajang Selangor, Kualu Lukat at Negeri Sembilan, Perak at Temong, Perlis at Kota Perlis, Johor at Batu Pahat, etc. The network, certainly confirms the strong influence of TNKB in Malaysia. ${ }^{47}$

However, it is important statement that TNKB is not the only Naqshbandiyya growing in Malaysia, because there are many other networks as an affirmation of the strong influence of the tariqa found in Malaysia. TNKB network in the region of Johor is as a major network of TNKB in Malaysia. This network is essential because Tuan Guru himself directly visits this area. One of the important TNKB network in Malaysia is a network in Johor which can be called a major network in Malaysia, because Tuan Guru himself has stayed in this area for a long time, specifically in Batu Pahat. Then of course a network trace of Tuan Guru in this area is clearly visible with several caliphs inaugurated be the "main agents" in this area particularly and generally in Malaysia such as Khalifah Umar, Khalifah Zakaria, Khalifah Muhammad and Khalifah Junaid, etc. ${ }^{48}$

Among them, the most prominent cliphs is Umar, because he builds a new TNKB network in Johor by setting up persulukan house which is very well known in Batu Pahat. Likewise, he actively involves in the deployment of TNKB network in Malaysia because he himself becomes a local murshid of TNKB in the area who also inaugurates

\footnotetext{
${ }^{46}$ Bruinessen, "After the Days of Abu Qubays", p. 138.

${ }^{47}$ Bruinessen, Tarekat Naqsyabandiyah, p. 135.

48 The names of TNKB caliphs from Malaysia refers to the record of the caliph in Babussalam Langkat.
} 
many caliphs from various regions in Malaysia. ${ }^{49}$ After the death of Khalifah Umar, TNKB network is reinforced by his zuriat, Khalifah Ishaq bin Ismail, who continues TNKB network and now it is continued by Khalifah Jahid Sidek who is capable of forming a network wider than ever, because Sidek is not only just able to present the knowledge of Tuan Guru, but more of which he himself is known as an academic at University of Malaya (UM).

So far, there are several persulukan houses specifically affiliated to TNKB, namely Rumah Suluk Guru (Selangor), Rumah Suluk Madrasah Babul Khayrat (Johor), Surau Suluk Madrasah Manaratil 'Ilmi (Pahang), Zawiyah Naqsyabandiyah (Terangganu), Madrasah Ustaz Suhaimi (Terengganu), Rumah Suluk Abdul Aziz (Terengganu), Rumah Suluk Hj. Osman (Selangor), Rumah Suluk Hj Rahman (Putrajaya), Rumah Suluk Hj Ikhwa (Selangor), etc (Abdullah, 2000, elMerbawi, 2012). Another TNKB network in Malaysia which can be also known from his network is Khalifah Usman (Johor), Khalifah Hasan (Perlis). Caliphs mentioned above after they died are replaced by their dburriyat such as Khalifah Dawi (Perak), Khalifah Muhammad Yatim. Then, the biggest TNKB network is led by Khalifah Yahya bin Laksamana domiciled in Kajang (Selangor). ${ }^{50}$

To that end, TNKB network is an important network in the Malay world because as mentioned before that strengthening of the network continues from "agents" caliphs to grow every day, then certainly the spread of TNKB in Malay world confirms that in a spiritual context, although both these areas limited by regions of the country, but the connection keeps continue until today. In addition, to the network mentioned is also found some other TNKB networks spread in several other areas in Malaysia such as Kuala Lumpur, Kelantan, Penang, and others. The deployment of TNKB network in Malaysia is still awakened by Babussalam, Langkat because now Tuan Guru of TNKB — which is in Langkat—also led persulukan in Malaysia, because Tuan Guru who is now noted also guides persulukan in several places in Malaysia as at Port Klang, Kedah, Kansas, and others. ${ }^{51}$

\footnotetext{
49 Abdul Manan bin Mohammad Al-Merbawi, "Tarekat Naqsyabandiyah Khalidiyah in Malaysia: A Study on the Leadership of Haji Ishaq bin Muhammad Arif," Miqot, 36:2 (2012), p. 46, Wan Mohd. Shaghir Abdullah, Penyebaran Thariqat-thariqat Shufiyah Mu'tabarah di Dunia Melayu (Kuala Lumpur: Khazanah Fathaniyah, 2000), p. 145.

${ }^{50}$ Siregar, “Tarekat Naqsyabandiyah”, p. 62.

${ }^{51}$ Interview with Athardin, 52 Years old.
} 
The new Tuan Guru of TNKB network mentioned earlier is certainly a part of strengthening the existing network, because TNKB network who has been there before to get a reinforcement of the new form through Tuan Guru networking, so the network of TNKB in Malaysia is an important network for TNKB in the Malay world. Additionally, the continuity pilgrims from Malaysia are also doing persulukan directly to Babussalam, which is considered as the "basecamp" of TNKB as other parts of the network that will strengthen the form of a network in Malay world, because — as far-pilgrims coming from Malaysia have almost never finished for doing persulukan or pilgrimage to Babussalam, Langkat.

\section{Conclusion}

The existence of TNKB in Malay world requires deeper exploration, since most of the research so far has been mere initial research. This paper contributes in providing a model of merger of several tariqas in TNKB. The merger between different elements of tariqa is quite common in the development of tariqa in Indonesia, combine with local culture (especially the Malay culture) the TNKB is the ideal model of Indonesian sufi. The successful story of TNKB is directly related to the dialectics of power and cordial relations with the Malay Sultan, which also confirm the importance of TNKB in Malay world, especially the inheritance model adopted by TNKB tariqa that would further expand its Malay world network in Indonesia and Malaysia.[]

\section{References}

\section{Books and Articles}

Abdullah, Wan Mohd. Shaghir, Penyebaran Thariqat-thariqat Shufiyah Mu'tabarah di Dunia Melayu. Kuala Lumpur: Khazanah Fathaniyah, 2000.

--------. Tarekat Naqsyabandiyah di Indonesia: Survei Historis, Geografis dan Sosiologis. Bandung: Mizan, 1994.

Fikri, Khairil. "Etnografi Suluk Tarekat Naqsyabandiyah-Khalidiyah Babussalam (TNKB)." Ziaulhaq Hidayat, Tarekat Naqsyabandiyah-Khalidiyah Babussalam (TNKB): Dari Doktrin, Seni bingga Arsiteketur. Jakarta: LSIP, 2015. 
Hadi, Syofyan. "Naskah Mawahib Rabb al-Falaq: Melacak Titik Temu Ajaran Dua Tarekat (Syazaliyah dan Naqsyabandiyah) di Minangkabau." Lektur Keagamaan, (11), 1, 2013.

Hamidy, U.U. Pengislaman Masyarakat Sakai oleb Tarekat Naksyabandiyah Babussalam. Riau: UIR Press, 1992.

Irham, M. Iqbal. "Pemikiran Sufistik Syekh Abdul Wahab Rokan." Jurnal Lektor Keagamaan, (8), 2, 2010.

Lombard, Denys. "Tarekat et Entreprise à Sumatra: L'exemple de Syekh Abdul Wahab Rokan (c.1830-1926)." Marc Gaborieau, et.al. (eds). Naqshbandis: Cheminements et Situation Actuelle d'un Ordre Mystique Musulman. Paris: Institut Français d'études Anatoliennes d'Istanbul, 1990.

Al-Merbawi, Abdul Manan bin Mohammad. "Tarekat Naqsyabandiyah Khalidiyah in Malaysia: A Study on the Leadership of Haji Ishaq bin Muhammad Arif." Miqot. (36), 2, 2012.

Muzakir. "Dari Sakral ke Profan: Globalisasi dan Komodifikasi dalam Dunia Spritual dengan Ilustrasi Tarekat NaqsyabandiyahKhalidiyah Babussalam (TNKB)." Akademika, (20), 1, 2015.

Perret, Daniel. " De la Forêt Primaire Aux Plantations Coloniales: Les Deux Ruptures Politiques et Socio-économiques de la Côte est de Sumatra-Nord." Bulletin de l'École française d'Extrême-Orient, 81, 1994.

-. La Formation d'un Paysage Ethnique Batak et Malais de Sumatra Nord-Est. Paris: Ecole francaise d'Extrême-Orient, 1995.

Rokan, 'Abd al-Wahab, Wasiat 44. n.p. : n.p., n.d.

Said, Fuad. Syeikh Abdul Wahab Rokan: Tuan Guru Babussalam. Medan: Pustaka Babussalam, 1983.

Siregar, Lisga Hidayat. "Tarekat Naqsyabandiyah Syekh 'Abdul Wahab Rokan Babusalam: Suatu Kajian tentang Ajaran dan Aktualisasinya dalam Kehidupan Sosial 1882-1926. Unpublished Ph.D dissertation, UIN Syarif Hidayatullah Jakarta, 2003.

Suparlan, Parsudi. Orang-orang Sakai di Riau: Masyarakat Terasing dalam Masyarakat Indonesia. Jakarta: Yayasan Obor Indonesia, 1995.

Sulanam. "From "Sufi Order Ritual" to Indonesian Islam." Journal of Indonesian Islam, 7 (1), 2013. 
Syukur, M. Amin and Abdul Muhaya. "al-Harakah al-Iqtisadiyah alSufiyyah fi Jawa: Dirasah Waqiiyah li Tariqah al-Qadiriyah wa Naqshabandiyah." Journal of Indonesian Islam, 9 (2), 2015.

Tajuddin. Sejarah Almarbum Waliyullab Qutubuzzaman Syeikh Abdul Wabab Rokan Tuan Guru Babussalam. n.p.: n.p., n.d.

van Bruinessen, Martin. "After the Days of Abu Qubays: Indonesian Transformations of the Naqshbandiyya Khalidiyah." Journal of the History of Sufisme. 21 (5), 2007.

Weismann, Itzchak. The Naqshbandiyya: Orthodoxy and Activism in a Wordwide Sufi Tradition. New York: Routledge, 2007.

Zamhari, Arif. "Social-Structural Innovations in Indonesia's Urban Sufism: The Case Study of the Majelis Dzikir and Shalawat Nurul Mustafa." Journal of Indonesian Islam, 7 (1), 2013.

Ziaulhaq. "Sharp Skullcap (Lobe Runcing) of Tariqa NaqshabandiyyaKhalidiyya Babussalam (TNKB): Identity, Sacredness and Commodity." Proceeding in International Conference on Southeast Asian Islam: Legacy and New Interpretation, UIN Jakarta, 2014b.

-------. "Tarekat Naqsyabandiyah-Khalidiyah Babussalam (TNKB): Situs, Silsilah dan Jaringan.” Jurnal Turats, (2), 1, 2014.

\section{Interview}

Athardin, 56 Years old (Zuriat of TNKB)

Shalahuddin, 41 Years old (Zuriat of TNKB)

Syarwani, Hasyim, 71 Years old (Tuan Guru of TNKB) 